\title{
Walking into the sunset: How criminal achievement shapes the desistance process
}

Sabrina Vidal, Ph. D Candidate, School of Criminology, Université de Montréal, sabrina.vidal@umontreal.ca;

Frédéric Ouellet, Associate Professor, School of Criminology, Université de Montréal, frederic.ouellet.1@umontreal.ca and;

Marie-Ève Dubois, Ph. D Student, School of Criminology, Université de Montréal, marie-eve.dubois.1@umontreal.ca

*The three authors contributed equally to the paper, reverse alphabetical order was used.

\section{Accepted Version}

Published in Criminal Justice and Behavior

Article first published online: April 2, 2020;

Link to article: https://journals.sagepub.com/doi/full/10.1177/0093854820913316

Correspond with: Sabrina Vidal

Sabrina.vidal@umontreal.ca

School of Criminology

Université de Montréal

C.P. 6128, succursale Centre-ville

Montréal QC H3C 3J7

Canada

\section{Acknowledgement}

We would like to thank all the individuals who participated in this study, their life stories were a great source of motivation. We would also like to thank le Fonds de Recherche du Québec Société et Culture for their financial support.

\section{Funding}

This research was funded via Le Fonds de Recherche du Québec -Société et Culture (FRQSC). 


\title{
Walking into the sunset: How criminal achievement affects the desistance process
}

\begin{abstract}
According to the criminal career paradigm, the link between past and future criminal activities is important and the desistance process may vary for individuals whose criminal trajectories were punctuated by failure compared to those who achieved a certain level of success. This study, based on the life narratives of 27 individuals who maintained a state of non-offending for more than a year, examines how criminal achievement modulates the desistance process. The aim is to understand whether criminal achievement acts as a barrier or a facilitator in the desistance process. A short questionnaire based on the life-history calendar method was used to classify individuals according to the parameters of their criminal careers. Narrative life stories were then used to look at the obstacles and frustrations encountered during desistance. The results show the relation between criminal achievement and desistance is complex: success in criminal activities is not always hindering desistance.
\end{abstract}

Keywords: Desistance, criminal achievement, criminal career, narrative life stories, life-history calendar 


\section{Introduction}

The link between past and future criminal behavior is well established in criminology (Farrington, 2003; Paternoster, Dean, Piquero, Mazerolle, \& Brame, 1997). The influence of past experiences on the structure of criminal careers and the desistance process has also been studied, but there is still more to learn about how achievement facilitates or hinders the desistance process. For instance, one of the experiences that can shape an individual's decision to continue with illegal activities is criminal success. Loughran, Paternoster, Piquero and Fagan (2012), working with a sample of juvenile delinquents, showed that undetected crimes can foster overconfidence, leading to a lower perception of the risk of arrest and an increase in the amount of crimes committed. Shover and Thompson (1992) found that individuals who are successful in crime are less likely to end their criminal careers (see also Charette, 2016; Piliavin, Gartner, Thornton, \& Matsueda, 1986). Furthermore, Ouellet (2019) has shown that variations in criminal achievement (impunity and income) greatly influence the timing of intermittency in individual trajectories, which suggests that criminal success (or failure) can affect both the continuity and desistance process of a criminal career. However, many theories about the desistance process have failed to incorporate this concept into their explanations (Ouellet \& Bouchard, 2017).

The present study, based on retrospective data collected through life history calendars and interviews with individuals involved mainly in lucrative crimes, examines the role of criminal achievement in the desistance process. Since most crimes are profit oriented (Uggen \& Thompson, 2003), it is important to look closely at the elements that facilitate or discourage the desistance of individuals involved in lucrative crimes such as robbery, drug trafficking and fraud. The findings from this study can therefore help guide social reintegration efforts. 


\section{Desistance}

It is becoming increasingly common to understand desistance as part of a process (Kazemian, 2016). Bushway, Piquero, Broidy, Cauffman, \& Mazerolle, (2001) discuss desistance as a gradual process rather than an abrupt transition to a crime-free lifestyle (see also Healy, 2010) and Maruna (2001) characterizes it as a gradual process that involves both stopping and maintaining abstinence from crime. The literature on desistance distinguishes three types of explanatory factors involved in this process: ontogenetic (see Harris, 2017; Hirschi \& Gottfredson, 1983), sociogenic (see Laub, Nagin, \& Sampson, 1998; Laub \& Sampson, 2003; Sampson \& Laub, 1993), and cognitive.

From the cognitive perspective, desistance occurs after a change in cognition or identity that leads to a rational decision to end a criminal career (Anderson \& McNeill, 2019; FortinDufour, Brassard, \& Martel, 2015). Paternoster and Bushway (2009) hold that identity change involves an individual's cognitive process, while Maruna (2001) underlines the role of the narrative script, arguing that desistance requires the development of a pro-social identity through the construction of a redemption script that makes it possible to redeem a shameful past as a prelude to choosing a new and productive life (Maruna, 2001). Fortin-Dufour and Brassard (2014) distinguish three processes or type of identity change that lead to desistance: the convert endorses a new identity that makes it possible to become a good citizen despite his past delinquency, the remorseful recognizes and repairs the fracture of identity that led to misconduct and returns to the socially accepted path, and the rescued is saved by a good Samaritan, who encourages the development of a pro-social identity. Looking more closely at the rational decision behind desistance, Sampson and Laub's theory suggest that desistance occurs when an individual encounter a turning point and makes a "situated choice" to act in accordance with the 
opportunity to change and bond with society (Laub \& Sampson, 2003, Sampson \& Laub, 1993). Traditional rational choice theories (see Becker, 1968) offer a somewhat less complex premise: people stop committing crimes when the expected consequences of offending outweigh the gain expected from the commission of a crime. On this theory, individuals are sensitive to the outcome of criminal activities and life experiences can affect the decision to desist from crime. Cornish and Clarke (1986) hypothesize that the accumulation of events from conventional and criminal life affect the decision-making process related to both the commission of crimes and desistance. Looking at this decision-making process, Cusson and Pinsonneault (1986) suggest that the experience of a "shock" while committing a crime can be linked to a "delayed deterrence" effect and are related to desistance. Such studies suggest that criminal achievement may be related to persistence in criminal activity while failure may be more likely to lead to desistance.

\section{Criminal achievement}

The sequence of crimes committed by an individual is not made up of isolated events or fortuitous coincidences but of interrelated episodes based on successive choices aimed at achieving the same ends (Hochstetler, 2002). Individuals are presumed to be rational beings whose involvement in crime is motivated primarily by the pursuit of benefits (Becker, 1968; Ehrlich, 1973; McCarthy, 2002). Although these benefits may take different forms (Pogarsky, Roche, \& Pickett, 2017), most crimes are financially motivated (Uggen \& Thompson, 2003). The concept of criminal achievement therefore considers both aims and achievements and can be measured by both objective and subjective indicators.

Criminal achievement has been studied from a number of different perspectives: impunity (Bouchard \& Nguyen, 2010; Kazemian \& LeBlanc, 2007), income generated from criminal 
activities (Loughran, Nguyen, Piquero, \& Fagan, 2013; McCarthy \& Hagan, 2001; Morselli \& Tremblay, 2004; Nguyen \& Bouchard, 2013; Nguyen \& Loughran, 2017; Nguyen, Loughran, Paternoster, Fagan, \& Piquero, 2017; Ouellet \& Tremblay, 2014; Uggen \& Thompson, 2003), perception of success (Brezina \& Topalli, 2012; Laferrière \& Morselli, 2015), reputation within a criminal network (Décary-Hetu \& Dupont, 2013; Tremblay, Charest, Charette, \& TremblayFaulkner, 2016; Tremblay \& Morselli, 2000), the effect of payment in kind (Nguyen \& Bouchard, 2013), and the position of a drug dealer in the distribution chain (Wang, 2013). These studies reveal differences in the level of criminal success as well as fluctuations in individual trajectories. Such inter- and intra-individual variations have been explained both by life circumstances (conventional and deviant) and the resources and skills of individuals.

Numerous studies have demonstrated the impact of criminal achievement on the course of the criminal journey and more specifically on the continuity of the criminal career. Successes extend the criminal career (Charette, 2016; Loughran, et al., 2012; McCarthy \& Hagan, 2001; Morselli, Tremblay, \& McCarthy, 2006; Nguyen, Loughran, Paternoster, Fagan, \& Piquero 2017; Ouellet, 2019; Ouellet \& Tremblay, 2014) while failures abridge this involvement (Anwar \& Loughran, 2011; Ouellet, 2019; Ouellet \& Tremblay, 2014). However, some research has gone further and shows a direct association between instances of failure and the decision to end a criminal career (Cusson \& Pinsonneault, 1986; Shover \& Thompson, 1992). As those studies demonstrate a link between failure and desistance, Sampson and Laub’s (1993) concept of cumulative disadvantage would suggest the opposite. Thereby, it would be easier to desist from crime for individuals who have been successful in avoiding sanctions; they would be less labelled and would have been able to maintain social bonds. Although this knowledge is useful, it does not explain how success in crime modulates the desistance process: what is the impact of 
criminal achievement on maintaining abstinence from crime or on the reintegration process? Can it make the desistance process easier or more difficult?

\section{Current Study}

The life course perspective focuses on the influence of life events on individual paths, particularly transitions and turning points that redirect these paths (Sampson \& Laub, 1993). Without neglecting the role of macro-level social structure, this perspective presupposes that individuals are rational beings and that the effects of their actions will have an impact on whether they choose to stop or continue their criminal activities. In other words, it is likely that desistance is understood and organized differently by individuals whose criminal career was punctuated by failures (e.g., multiple arrests and incarcerations) compared to individuals who achieved a certain level of success in their criminal activities (e.g., impunity, significant criminal earnings). Life course and rational choice theories, which give individuals an active role in the decision to end or continue their involvement in crime, thus appear to be useful in understanding the desistance process.

In this paper, we examine the role of criminal achievement as a barrier to or facilitator of the desistance process. A short questionnaire based on the life-history calendar method was used to obtain self-reported information on criminal involvement that allowed us to classify individuals into three groups according to the parameters of their careers, especially the level of criminal success. Narrative life stories were then obtained to capture the dynamics of the desistance process. Information gained from these two steps was used to examine whether the desistance process differed between groups, fostering an understanding of turning points in criminal careers and the processes that explain continuity and discontinuity, as well as providing information to guide the development of reintegration programs. 


\section{Data and method}

\section{Participants}

To examine whether criminal achievement has an impact on the desistance process, 27 individuals in the province of Quebec were recruited between 2015 and 2017. Planned interviews, whose main purpose was to let the participants "tell their story", lasted approximately 2 hours, including completing a short questionnaire about the parameters of their past criminal careers. Our methodology drew heavily on the Liverpool Desistance Study (Maruna, 2001), making it possible to compare and draw parallels between the two studies. Three criteria were used to select participants, two of which were like criteria used by Maruna (2001). First, participants had to identify themselves as desisters, meaning that they had indicated that they would not be committing crimes in the future and their last crime was at least 1 year before taking part in the study. While, as Maruna argued, identifying the moment when desistance occurred is trivial (see Kazemian, 2016; Maruna, Immarigeon, \& Lebel, 2013; Maruna, Lebel, Mitchell, \& Naples, 2009), using this criteria - even if vague - excluded people who were "between" desistance and persistence. On average at the time of interview, participants had abstained from crime for 3.5 years and the purpose of the current study was to examine whether there was an intention to maintain this state of non-offending. Second, participants had to have taken part in sustained and regular criminal involvement during their criminal careers - we were looking for individuals who had been active in crime on a near-monthly basis for at least two years. Third, the bulk of the crimes committed by the participants during their criminal careers had to involve financially lucrative crimes (e.g., robbery, drug trafficking, fraud, etc.). To sum up, whereas prior studies often compared desisters to non-desisters according to some 
measurable criteria, the purpose of the current study was to recruit only individuals that met our conceptualization of desistance.

Multiple recruitment strategies were used. The research project was announced on social networks, which enabled us to recruit 11 participants. Participants were also solicited through information from individuals involved with the School of Criminology of the University of Montreal (those in field placements as well as former students who were employed as probation officers, social workers, halfway house workers, or in reentry programs) (N=9). In addition, a snowball sampling technique was employed in which participants were used as a source of identification to find additional participants $(\mathrm{N}=7)$. Participants were mostly men $(92.6 \%)$ and on average 38.4 years old. All were French speaking. Participants were also mostly Canadian (92.6\%) and single at the time of the interview (70.4\%). As for the highest level of education reached, $25.9 \%$ of the participants had not finished high school, $14.8 \%$ had a high school diploma, 37\% had vocational school or a college diploma (Quebec institution of post-secondary education intended for pre-university programs and technical training), and $22.2 \%$ had a university degree. It is noteworthy that almost $60 \%$ of the sample had been single and unemployed for more than half their adult life.

\section{Procedures and instruments}

During meetings with participants, a questionnaire based on the life history calendar method was administered to collect self-reported information on both overall criminal career, context and life circumstances. Life history calendars are used to outline individual paths (Caspi, Moffitt, Thornton, Freedman, Amell, Harrington, Smeijers, \& Silva, 1996) and have two undeniable advantages for collecting retrospective data. First, they improve the quality of the data by helping the participant link, both visually and mentally, several types of events 
(Freedman, Thornton, Camburn, Alwin, \& Young-DeMarco, 1988). Second, they make it possible to gather information about both transitions and an event's causal chain (Freedman, et al., 1988). The validity and reliability of the data resulting from this method has been demonstrated in many studies (Axinn, Pearce \& Ghimire, 1999; Belli, 1998; Belli, Shay, \& Stafford, 2001; Caspi, et al., 1996; Charest, 2004; Sutton, Bellair, Kowalski, Light, \& Hutcherson, 2011). More important for our study, this method has also been found to be reliable in estimating criminal earnings for incarcerated adults (Charest, 2004).

The questionnaire developed for this project was divided into themes and years and covered the participants' life course from childhood to the time of the interview. It took an average of 30 minutes to complete. This research method is adapted to the structure of autobiographical memory, particularly the sequential and hierarchical storage of memory, facilitating the recall of events (Belli, 1998). The themes discussed begin with events that are more meaningful or easier to remember as this helps contextualize other events. In this study, themes were selected for their theoretical relevance as well as to deal with specific research interests. More specifically, the calendar included on a yearly basis and for the lifespan : relationships with significant others (if any), occupied jobs, types of crimes committed, legal and illegal income, arrest, episodes of incarceration and any special events considered important by the participant (e.g., birth of a child or the death of a relative). These elements were all selfreported as no official data was collected and compared to the answer provided in this study. The questionnaire also proved to be useful in the interviews, giving participants benchmarks around which, they could organize and structure their autobiographical narrative, helping establish the chronology of events. Our experience agrees with that of other studies (Belli, et al., 2001; Yoshihama, Gillespie, Hammock, Belli, \& Tolman, 2005) that had found this methodology 
useful in qualitative research as it stimulates discussion about past experiences and the underlying processes that explain behavior, attitudes and emotions. Data from life history calendars was used primarily for descriptive purposes and for comparison: the main source of data was the life stories of the participants.

Once the life history calendars were completed, semi-structured interviews were conducted to let participants tell their own stories. The study of life stories is a qualitative method aimed at reconstructing the subjective experience of the participant around a narrative identity (Josselson \& Lieblich, 1993; Maruna, 2001; McAdams, 1985). The emphasis is not so much on the elements in the narrative itself as on the meaning that the participant gives them. Given our interest in the narrative of desisters, the methodology employed in our interviews drew heavily on that used in the Liverpool Desistance Study (Maruna, 2001). On this approach, each participant was asked to "tell their story": "During the interview, I would like us to address the following topics: your life history/trajectory, your criminal path, your criminal achievement, your desistance, maintaining your desistance, and changes in your life. With these areas in mind, can you tell me about your life up until you stopped criminal activities?" The interview process was guided by a grid that set out the themes and subtopics to be addressed. Six themes were covered: life course in general, criminal path, criminal achievement, desistance from crime, maintenance of desistance, and changes in identity (if mentioned during the interview). These interviews were conducted by two trained research assistants and one of the authors.

\section{Analytical strategy}

To explore how criminal achievement might affect the desistance process, we used a twostep analysis strategy. The first step was to classify individuals according to objective indicators of criminal achievement (criminal earnings, arrests). Descriptive statistics in data collected using 
the life history calendars (self-report questionnaire) made it possible to compare average criminal achievement per individual. (How these groups were formed is detailed in the results section.) The second step was to examine how participants perceived their criminal achievements and to explore whether the desistance process differed between different groups of individuals. A thematic analysis of the transcripts of narrative life stories was then carried out. This thematic analysis allowed us to identify recurring themes as well as their importance in the participant's narrative. Interviews were read both vertically and horizontally. The former reading maintained the logic of each participant while the latter made it possible to establish relationships with other interviewees. At this point, each of the three researchers (authors of this article) analyzed the verbatim from two of the three groups of participants. In other words, each group underwent an independent in-depth examination twice. Those involved in the analysis then compared their results to reach a consensus. If there was continuing disagreement, the third author acted as arbitrator.

\section{Results}

To contextualize our findings on criminal achievement and the desistance process, it is important to outline the parameters of the criminal careers of the participants. On average, participants had started their criminal careers a little past their 18th birthday (18.5 years old); onset (age at which participants said they had committed their first crime) varied between 11 and 35 years of age. It is possible that the somewhat late entry into criminal activity is explained by the nature of the criminal activities committed by the selected participants: Donnellan, Ge, and Wenk (2002) found that adult-onset offenders had more skills and were more motivated to succeed in crime than adolescent delinquents. The average length of participants' criminal careers was 16 years (15.8). Most participants reported ongoing (67\%) rather than intermittent 
(33\%) criminal activity. In other words, two-thirds of participants had taken part in criminal activity every year throughout their criminal career. With respect to types of criminal activities, participants had committed an average of 2.5 different types of crimes during their criminal careers and a significant proportion of individuals (29.6\%) had specialized in one type of crime. The most common types of criminal activity in the sample were drug resale and distribution $(85.2 \%)$, theft $(40.7 \%)$, burglary $(29.6 \%)$, robbery $(25.9 \%)$ and fraud $(22.2 \%)$. A significant proportion of participants $(77.8 \%)$ experienced an incarceration episode during their criminal journey. For five of these participants (23.8\%), time spent in prison was less than one year. Only one of the participants never had contact with the authorities (no arrest and no detention).

\section{Criminal Achievement}

Our research investigates the effect of criminal achievement on the desistance process. In doing this, it is important to examine how participants measure and perceive their criminal success since individual perceptions may not only differ from objective indicators of success but may be more effective in explaining the decision to desist from crime. To compare criminal achievement, participants were divided into three groups according to five objective indicators of criminal achievement: total earnings during criminal career, total earnings divided by the number of years active in crime, total years spent incarcerated, time incarcerated divided by the length of the criminal career, and number of arrests. Rankings for each participant were then calculated and averages and standard deviations were determined. For example, the participant with the highest total of criminal earnings was given the highest rank, while the participant with the lowest criminal earnings received the lowest rank. Three groups, each consisting of 9 individuals, stood out. The first Group consisted of the least successful participants as indicated by their low rankings on earnings and high rankings on incarceration and arrests. A second 
Group consisted of participants with average earnings and average incarceration and arrests, while a third Group had high earnings and low rates of incarceration and arrests (descriptive statistics for these three groups are presented in Table 1). Average criminal earnings per year for the first Group were 36 090\$, which is low when compared to the second (91 591\$) and third (217 466\$) Group. The average annual illegal income of participants is very similar to that found in similar samples in which involvement mainly in lucrative forms of crimes was used as a selection criterion (e.g., Ouellet, 2019; Ouellet and Bouchard, 2017; Morselli and Tremblay, 2004). A similar trend was found for incarceration (duration and relative duration) and arrests. These results suggest, following Tremblay and Morselli (2000) that there are different models of criminal success, which may indicate that not all individuals who offend are equally competent. Individuals who obtain a higher pay-off from their crimes may also be less likely to be arrested or incarcerated, suggesting the existence of a skill set, or competence, that leads to increased criminal achievement. These findings are in line with Ouellet and Bouchard's (2017) results, which suggest a link between risk avoidance and illegal earnings, two objective measures of criminal achievement.

\section{Perception of criminal achievement}

The first Group demonstrated the "classic" criminal trajectory described in criminological research, which is characterized by the presence of numerous risk factors (e.g., poor parental supervision, poverty), early initiation to crime (14.9 years of age), substance use problems, and lengthy periods of incarceration. The crimes committed by this Group tended to be opportunistic and motivated by the criminal lifestyle. Based on sanctions received but also because the path taken severely reduced the scope of their post-criminal career opportunities (having led to little 
education or work experience), these participants admitted that they had had little success in their criminal careers.

Participant 24 (Robbery and burglary; desisted from crime for 7 years) I didn't have success. I would say that I had good times, but I cannot say that I was successful. Far from it, y'know, because seriously, with hindsight, it really does not make sense for what it brings in the end. Unless you're profitable and you're making millions. Otherwise it's not worth it. (All quotations were originally in French but were translated by the authors.)

Individuals in the second Group were distinguished by their late entry into crime $(20.2$ years of age on average) relative to the first Group and by the fact that many in this group had had legitimate jobs before committing crime. For them, involvement in crime was explained by its financial attractions as well as the opportunity to gain recognition from their peers. When asked about the success of their criminal activities, these individuals were ambivalent. Although most believed that they had been fully committed to a criminal career, they regretted that there had been no tangible benefit from this involvement - despite having generated significant income during their criminal career, once it ended they had no financial assets, which they saw as indicative of failure. The motivation of participants in the second Group was mainly monetary. However, for some individuals in this Group, success was indicated by the human capital they developed during their criminal careers. They saw themselves as successful because of the network they had built and the reputation they had acquired in criminal circles.

Participant 19 (Drug trafficking, desisted from crime for 1 year)

Zero, Absolutely Zero, In terms of money, it's bad. I made a lot of money but spent it all. The money doesn't exist anymore ... But in terms of human connections, I'd tell you that my criminal life was successful in the sense that I was able to build a network. I worked for everyone. I wanted to meet everyone. I wanted to learn everything and was able to build relationships. It was cool and went well, contrary to the money side of things. 
The criminal careers of participants in the third Group began early in adulthood (18.2 years of age on average). When periods of incarceration are subtracted from the duration of criminal careers, this group of participants were active in crime for the longest. They stand out from other groups in their view of their criminal activities, which they consider to be just like the management of any business. They see themselves as entrepreneurs and leaders of a group. These individuals, who were generally involved in market crime, saw themselves as successful according to their position in their criminal network. As one of them said:

Participant 2 (Drug trafficking and vehicle theft, desisted from crime for 7 years) I carried those people; I hired those people. So personally, I did not work, I delegated. I was just the pivot in drug trafficking, between buying and redistributing. So, it was really easy, but yeah, it was too much money for what I was doing. I did not do anything ... I worked like 1 hour a day ... I said "hello", "bye", then it was over.

While the participants in Group 3 agreed that criminal success is measured by criminal earnings, their position in a criminal network and the skills they developed were also very important to them. The importance they placed on human capital as well as criminal competence makes them stand out from the other two groups. Most of the members in Group 3 saw themselves as involved in consensual crime: their crimes involved selling goods as part of a consensual agreement and the people they dealt with were clients, not victims. This view could be an example of Maruna's (2001) description of the way individuals change the way they interpret their past in order to align past activities with their current selves. The definition of success varied across groups and was not merely a question of tangible or objectively observable benefits (criminal income and avoidance of sanctions) but also of reputation and human capital. 


\section{Desistance Process}

The desistance process for individuals in Group 1 was a gradual process that led to an identity change or to a deconstruction of the image, they had had of themselves. As one participant stated: "In the end, I'm not like that [a criminal], I'm a good guy. After repeatedly telling myself that, I finally believe it." (Participant 1, drug trafficking and theft, desisted from crime for 3 years). For these individuals, desistance involved endorsing a new social identity. The following quote shows the transition to a prosocial identity:

Participant 13 (Theft, desisted from crime for 1 year)

Most of the work is done inside your own head. To change, I had to work hard on my mindset, and once it changed, I had to work even harder to maintain it.

This barrier-prone process was usually fostered by participation in programs and therapies aimed at addressing psychotropic addiction issues. Undertaking the desistance process was attributed to the fatigue and stress caused by the criminal lifestyle as well as failures (sanctions), which often had the effect of consolidating desistance.

Participant 24 (Robbery and burglary; desisted from crime for 7 years)

It is a rather difficult way of life, quite stressful too ... Of course, there is the income, but you know, it's either living at $\$ 200,000$ a year with stress and dying from a heart attack at less than 30 years old or living at $\$ 30-\$ 40-\$ 50000$ per year with a job you like.

The work and effort invested in reintegration were also factors that kept participants from reoffending. For some, the thought of losing what they had worked hard to build after abandoning their criminal careers motivated them not to return to crime.

Participant 5 (Theft, drug trafficking, and fraud, desisted from crime for 8 years). My life today keeps me from reoffending because I do not want to lose what I have. I do not have much, but what I have, I do not want to lose. 
For individuals in Group 2 and 3, as opposed to Group 1, the desistance process and its maintenance were simpler: they had never identified as criminals and were also better educated and had had legitimate work experience prior to their entry into crime, which greatly facilitated social reintegration. Having never adopted a criminal identity, they did not need to change the way they saw themselves to desist. As a participant from the third Group said:

Participant 2 (Drug trafficking and vehicle theft, desisted from crime for 7 years) But I'm going to be honest with you, I do not consider myself a criminal and the people who were with me [co-offenders] will tell you the same thing. We were all good people and you know, I mean, we did silly things, but you know, there was never anyone who was hurt.

Instead of having to change their identity, they had to return to be the individuals they had been before they embraced a criminal career. For these individuals (Groups 2 and 3), involvement in crime was not explained only by financial success but was also supported by recognition from others and accumulated human capital. They valued themselves on the networks they had built, their reputation and the criminal skills they acquired. However, the way they had achieved monetary success had a direct impact on their desistance: limits on the use of the proceeds from crime were identified as an obstacle to the criminal career. The inability to save without raising suspicion and the obligation to launder or spend the money (in partying or gambling) were experienced as major irritants. Individuals in Groups 2 and 3 differ in the way criminal success affected the desistance process. For those in Group 2 criminal success weakened the desistance process and made it harder to maintain as they always have the option to return to crime if they were in need. They liked money and wanted a high standard of living their success in crime shaped their expectations for conventional life. For them, having the motivation and will to continue the desistance process required interesting and profitable job opportunities. A participant expressed this position clearly: 
Participant 4 (Corruption and drug trafficking, desisted from crime for 4 years) And now, I make money and I don't need to go back ...I don't know if you understand what I mean... I don't need to sell [drugs] anymore. I sleep well, I can buy myself anything I want.

Individuals in the Group 3 believed the skills acquired during their criminal careers (e.g., entrepreneurial skills) could be transferred to conventional life, thus facilitating their return to it. However, as they had key roles in small criminal networks, abandoning a criminal career was a gradual process rather than a spontaneous event. They had to plan their exit - being key players, they had to find a way to compensate others for the loss of income and/or find a replacement to take their position in the network. In this sense, achievement in criminal networks became an obstacle to desistance. For example, in the drug distribution business quitting without finding a replacement would have had an impact on the supply chain, preventing clients from obtaining drugs and leading to a loss of income for members higher in the drug distribution network.

Participant 2 (Drug trafficking and vehicle theft, desisted from crime for 7 years) No, I was having fun, so I was successful. But I also remember quitting, you can't leave whenever you want in this field. There are steps that need to be followed in order to leave. You need to talk to people... They are...How can I explain... It's like in business ...If I were a supplier in a store and that store brought me a certain amount each week, I couldn't just stop supplying it... There are steps to be followed before leaving.

Participant 9 (Drug trafficking, desisted from crime for 1 year)

To get out, he didn't want me to quit, he saw that I was efficient, so he didn't want me to quit. So, I left but they found me, I had to pay, and it cost me a lot of money to be able to quit, but it was worth it.

In contrast to Group 2, who were motivated by money, participants in the third Group emphasized the importance of finding other challenges or opportunities as part of returning to conventional life. From their perspective, they were more important than remuneration. 
Participant 2 (Drug trafficking and theft, desisted from crime for 7 years) It was not a question of money [that led to criminal activity] ... The money you have doesn't matter as long as you have enough. But for me, it's because I like the challenge, it's mainly for the challenge, so I had to look for the challenge elsewhere.... I found this challenge in my new job. It is something rewarding. I mean, it's important to love what you do and it's important that you value it.

For participants in Group 1, the lack of criminal achievement facilitated the desistance process, as the negative effect of sanctions and lack of earnings eventually led them to think about returning to conventional life, even if the process relied on an identity change. For those in Group 2, criminal achievement acted as a barrier to desistance as it shaped their expectations of legitimate earnings. Those in Group 3 were able to recognize not only the skills they had acquired and their impact on criminal achievement but also how those skills could be used in legitimate fields, facilitating the desistance process. However, their success was the result of having held key roles and therefore they needed to find replacements to be able to desist from crime. In this sense, their criminal achievement also hindered their desistance process.

\section{Effect of life circumstances}

Our analysis of narrative life stories also highlighted the relevance of particular events in the desistance process. These events were found in the life stories of all participants and were associated with transitions in their criminal trajectory. Although it was not possible to differentiate between the groups based on the strength or nature of these experiences, it was possible to identify two types of events: (1) events that influence the desistance process through criminal achievement and (2) other life events (positive or negative) perceived as important in the process leading to the end of a criminal career.

The first type of event can encourage or delay desistance. Events related to success encourage continuity in a criminal career. For example, the criminal trajectories of many of those we interviewed were affected by meeting a key contact in a specific criminal network. One of 
our participants, a drug trafficker, met a chemist who produced synthetic drugs. Adding the producer's drugs to his merchandise made it possible to diversify his criminal activities from selling only cannabis to selling synthetic drugs, which led to new customers and increased the size of his network. His criminal affiliations deepened his criminal ties and fostered his criminal trajectory. A participant involved in robberies met a contact part of a network of fences that specialized in stolen goods. This contact enabled him to sell stolen goods more efficiently and increase earnings from his criminal activities. These results support the findings of Morselli, Tremblay and McCarthy (2006) that individuals share criminal expertise between each other.

Otherwise, events associated with failure in crime incited or consolidated desistance. For example, for some participants the failure of co-offenders had an impact on the decision process. The arrest of a friend played a role in the trajectory of one of the participants, making him realize the risks associated with his criminal activities and leading him to reduce the potential legal consequences of his activities going from selling synthetic drugs to selling cannabis, which he saw as a safer criminal activity. Although his criminal career did not end at that moment, his friend's arrest may have function as a "shock" leading to a "delayed desistance" as explained by Cusson and Pinsonneault (1986).

Other events also modulated the desistance of participants. For instance, taking a new drug sometimes promoted the continuation of a criminal career - a few participants had begun using new drugs leading to an increase in their involvement in crime in order to afford their new addictions. Events such as the death of a relative or sexual assault were also described as having galvanized criminal careers: participants sometimes said these events had led to destructive behaviors such as alcohol or drug consumption in an attempt to numb the pain, which then led to theft and other acquisitive criminal behavior. The death of a relative may also decrease positive 
social influences and contribute to continuing a criminal career. Interviews with several participants highlighted the importance of a pro-social actor, someone who was willing to give a chance or believe in their willingness to end a criminal career. These results agree with those of several studies that show the importance of social support in the desistance process (Giordano, 2016; Giordano, Cernkovich, \& Rudolph, 2002; Maruna, et al., 2009). In our study, such prosocial actors held various roles (e.g., friend, parole officer, ex-offender) and assisted desisters in different ways (e.g., helping them find a job, giving advice, providing support).

Our results show that desistance is affected by particular events, not only those associated with success or failure in crime but those involving social relationships. Some relationships constrained or delayed the beginning of the desistance process, while others promoted or consolidated it, showing that events during the criminal career influence the desistance process.

\section{Discussion}

The purpose of this research was to dive onto the life trajectory of a group of individuals involved mainly in lucrative crimes, using narrative life stories and life history calendars to explore both criminal context and the desistance process. The main question was whether characteristics of criminal involvement, particularly success in crime, affect desistance and its maintenance. We were interested in the impact of criminal achievement - whether the level of success achieved by individuals is a barrier to or a facilitator of the desistance process. It should be noted that few empirical studies have explored the links between the characteristics, events, and experiences that influence criminal careers, specifically criminal achievement and the desistance process. Although the link between past and future criminal behavior is well established (Farrington, 2003; Paternoster, et al., 1997), there is still more to learn about how criminal achievement facilitates or hinders the desistance process. In fact, in many studies on the 
end of criminal careers participants were selected based on abandonment criteria (e.g., duration of abstinence from crime), with little regard to the level of success during the criminal career. The contribution of this study thus lies in the elaboration of potential links between the details of criminal involvement, such as criminal achievement, and the desistance process.

To examine the impact of criminal achievement on the desistance process, a short questionnaire using the life history calendar method was administered to collect information about different trajectories (e.g., employment, intimate relationship) as well as the parameters of the criminal career. This method contributed to the results in two ways. First, describing different trajectories and locating important life events along a timeline allowed participants to visualize benchmarks, making it possible to provide richer life stories. Second, information on objective indicators of criminal achievement, collected through the calendars, made it possible to divide individuals into three groups based on important differences regarding criminal income and impunity. The collected data allowed us to identify models of criminal achievement (Tremblay \& Morselli, 2000) and to explore the impact of criminal success on the desistance process.

Our results show that the course of a criminal career matters in understanding the desistance process as there are many paths to desistance. For Group 1, desistance is a process with obstacles and is marked by a change in identity, suggesting that the desistance process of these participants might be better explained by life-course theories. The difficulties encountered during the desistance process are in part attributable to the early onset of a criminal career and the consequences associated with the adoption of such a lifestyle. For example, dropping out of high school limits legitimate work opportunities, which can lengthen the criminal career and complicate the process of desistance. These individuals, like Maruna's desisters (2001) and Fortin-Dufour's converts (Fortin-Dufour, et al., 2015), need to adopt a new social identity to 
desist from crime. Endorsement of this new identity is fostered by positive family relationships, employment, or participation in various programs. Although identity change is an internal factor, such a redefinition of the self is possible only if supported by the social structures, as Giordano and colleagues (2002) argue (see also Cid \& Marti, 2017; Maruna, et al., 2009). Desistance for Group 1 thus relies on support for change, which makes them vulnerable to relapses, especially given the many barriers that characterize their paths.

For individuals in Groups 2 and 3, who started their criminal careers when they were older, crime played a more instrumental and calculated role in their lives: in order to desist, these individuals had to modify the means (legitimate vs illegal activities) they used to reach the same end, which is to earn money. Transition to conventional life was therefore easier for these individuals as it did not require a profound change in identity but instead necessitated finding a way to repair their crime-tainted identities. Like the remorseful described by Fortin-Dufour and Brassard (2014), they needed to return to the self they were before they began committing crimes. These individuals saw themselves as a key element in their desistance, with their desistance, the result of a personal choice. These results are in line with Cornish and Clarke's (1986) hypothesis that the cumulation of events in the criminal and legitimate life can affect the decision that leads to desistance. These individuals were able to be more autonomous in their approach to change and less dependent on external forces. The different characteristics of the three groups suggest that age of onset affects not only the duration of involvement in crime but also the desistance process. This is in line with Moffitt (1993), who recognizes that individuals with a late entry into crime (late starters) stand out from those with an early age of onset (early starters), particularly in their relationship to society. The path taken depends, at least in part, on past experiences, an association explained by the life course theoretical perspective and the 
principles of cumulative continuity and self-selection (Benson, 2012). The importance of the life course perspective is also highlighted by the need to understand the effect of specific events on the path pursued: events/experiences during a criminal career have the power to influence, positively or negatively, involvement in illicit activities. The purposes of crime distinguish individuals in Group 2 from those in Group 3. Individuals in Group 2 are motivated by the money and lifestyle that goes along with a criminal career. Their desistance is therefore precarious insofar as abstinence from crime depends on the availability of financial resources. Above all, they need a well-paying job to maintain the lavish lifestyle adopted during their criminal career. Although the monetary aspect was important for individuals in Group 3, their criminal involvement was driven more by the challenges posed by criminal activities (thrill, strategies, and skills). New challenges that can provide sensations like those of criminal activities were essential to their desistance. Different theoretical currents can be used to explain the paths of the participants. For example, cognitive theories (Giordano, et al., 2002; Maruna, 2001; Paternoster \& Bushway, 2009) are essential to making sense of the shift in identity experienced by Group 1 and the repair of identity fracture by those in the other groups. Life-course theories (such as Laub \& Sampson, 2003; Sampson \& Laub, 1993) and the rational choice perspective (Becker, 1968; Cusson \& Pinsonneault, 1986) are better suited to explaining the effects of the events identified in this research. Only a combination of these theoretical frameworks makes it possible to understand the full picture. The sequence of crimes committed by individuals is not made up of isolated events or fortuitous coincidences but of interrelated episodes of successive choices with the same motivation (Hochstetler, 2002). Individuals are presumed to be rational beings whose involvement in crime is primarily motivated by profit and by avoiding cost (Becker, 1968; Ehrlich, 1973; McCarthy, 2002). The benefits of crime can take different forms 
(Pogarsky, et al., 2017) and our study suggests that these benefits can be both objective (criminal earnings, experience of impunity) and subjective (social and human capital, reputation). Criminal achievement was found to influence both career continuity and the desistance process. In general, success tends to hinder desistance, while failure is likely to encourage the process of desistance. For individuals in Group 1, fatigue with the criminal lifestyle and failures in crime (e.g., arrest, incarceration) were important factors in the initiation of the desistance process. Failures also reinforced pro-social reform. The motives behind the decision of those in Groups 2 and 3 to leave a criminal career are more complicated, as this career brought significant benefits. To justify their decision, they mentioned the stress associated with this lifestyle. Their inability to save money or to use their criminal earnings without having to launder it also had an impact on the initiation of the desistance process. Over time, participants became more aware of or fearful of the risks associated with their activities. However, counteracting the idea that criminal achievement is a barrier to desistance, these individuals reported a possible transfer of criminal competence to legitimate activities. In this context, criminal achievement can promote social reintegration. Success in crime greatly influenced perception of the cost/benefit ratio, which in turn modulated onset, continuity, and the end of criminal careers.

Some limitations on the data used and the analysis performed must be considered in interpreting our results. This research focuses on the criminal careers of a small number of individuals involved in lucrative forms of criminal activity, which limits generalization of the results as individuals in this study cannot be considered to be representative of individuals involved in lucrative crimes, either in terms of individual characteristics or criminal career parameters. Moreover, empirical saturation was not necessarily reached, but very few new elements emerged in the last interviews. Finally, the data underlying this study, both from life 
history calendars and from interviews, depend on participants' memories and one can assume that the ability to recall the details and events of a criminal career vary between individuals.

\section{Conclusion}

This research project aimed to outline the criminal path of each participant to study the dynamics of desistance and its maintenance. Our findings highlight the importance of identifying motivations behind criminal involvement and the level of success in crime to understanding the process leading to the end of criminal careers. In fact, results show that the link between criminal achievement and desistance is complex: success in criminal activities is not always hindering desistance. Life stories highlighted different patterns of desistance which are modulated by the level of success, the purpose of criminal involvement, personal identities and life circumstances. This study suggests criminal achievement as a central parameter of a criminal career, through its influence on decisions, since it has a structuring effect on other career parameters. The competence and skills of successful individuals also influence the desistance process by modifying the individual's point of departure for social reintegration. These results have interesting implications for the field of reentry. Since the study highlights different paths to desistance, those dealing with programs supporting desistance could take into account the characteristics of the criminal careers, such as level of criminal achievement and purpose to align interventions with those characteristics. This study suggests several other interesting areas to pursue, such as examination of the process by which criminal skills are learned and how these skills can be used in reintegration. It would also be relevant to extend our model to consider the purposes and level of criminal achievement in other types of criminal trajectories. 


\section{Références}

Anderson, S., \& McNeill, F. (2019). Desistance and cognitive transformations. In D. P. Farrington, L. Kazemian, \& A. R. Piquero (Eds.), The Oxford handbook of developmental and life-course criminology (pp.600-623). Oxford University Press.

Axinn, W. G., Pearce, L. D., \& Ghimire, D. (1999). Innovations in life history calendar applications. Social Science Research, 28(3), 243-264.

Becker, G. S. (1968). Crime and punishment: An economic approach. In N. G. Fielding, \& R. Witt (Eds.), The economic dimensions of crime (pp. 13-68). Palgrave Macmillan.

Belli, R. F. (1998). The structure of autobiographical memory and the event history calendar: Potential improvements in the quality of retrospective reports in surveys. Memory, 6(4), 383-406.

Belli, R. F., Shay, W. L., \& Stafford, F. P. (2001). Event history calendars and question list surveys: A direct comparison of interviewing methods. Public Opinion Quarterly, 65(1), 45-74.

Benson, M. (2012). Crime and the life course (2nd ed.). Routledge.

Bouchard, M., \& Nguyen, H. (2010). Is it who you know, or how many that counts? Criminal networks and cost avoidance in a sample of young offenders. Justice Quarterly, 27(1), $130-158$.

Brezina, T., \& Topalli, V. (2012). Criminal self-efficacy: Exploring the correlates and consequences of a "successful criminal" identity. Criminal Justice and Behavior, 39(8), 1042-1062.

Bushway, S. D., Piquero, A. R., Broidy, L. M., Cauffman, E., \& Mazerolle, P. (2001). An empirical framework for studying desistance as a process. Criminology, 39(2), 491-516. 
Caspi, A., Moffitt, T. E., Thornton, A., Freedman, D., Amell, J. W., Harrington, H., Smeijers, J. \& Silva, P. A. (1996). The life history calendar: A research and clinical assessment method for collecting retrospective event-history data. International Journal of Methods in Psychiatric Research, 6(2), 101-114.

Charest, M. (2004). Peut-on se fier aux délinquants pour estimer leurs gains criminels? [Can we rely on delinquents to estimate their criminal revenues?]. Criminologie, 37(2), 63-87.

Charette, Y. (2016). L'impact des expériences d'impunité sur les risques de récidive pénale [The impact of experiences of impunity on the risk of reoffending]. Canadian Journal of Criminology and Criminal Justice, 58(4), 565-597.

Cid, J., \& Martí, J. (2017). Imprisonment, social support, and desistance: A theoretical approach to pathways of desistance and persistence for imprisoned men. International Journal of Offender Therapy and Comparative Criminology, 61(13), 1433-1454.

Cornish, D., \& Clarke, R. (1986), Situational prevention, displacement of crime, and rational choice theory, In K. Heal and G. Laycock (Eds.), Situational Crime Prevention: From Theory to Practice. Routledge.

Cusson, M., \& Pinsonneault, P. (1986). The decision to give up crime, In D.B. Cornish \& R.V. Clarke (Eds.), The reasoning (Rational choice perspectives on offending) (pp.72-80). Transaction Publishers.

Décary-Hétu, D., \& Dupont, B. (2013). Reputation in a dark network of online criminals. Global Crime, 14(2-3), 175-196.

Donnellan, M. B., Ge, X., \& Wenk, E. (2002). Personality characteristics of juvenile offenders: Differences in the CPI by age at first arrest and frequency of offending. Personality and Individual Differences, 33(5), 727-740. 
Ehrlich, I. (1973). Participation in illegitimate activities: A theoretical and empirical investigation. Journal of Political Economy, 81(3), 521-565.

Farrington, D. P. (2003). Developmental and life-course criminology: Key theoretical and empirical issues-the 2002 Sutherland award address. Criminology, 41(2), 221-225.

Fortin-Dufour, I., \& Brassard, R. (2014). The convert, the remorseful and the rescued: Three different processes of desistance from crime. Australian \& New Zealand Journal of Criminology, 47(3), 313-335.

Fortin-Dufour, I., Brassard, R., \& Martel, J. (2015). An integrative approach to apprehend desistance. International Journal of Offender Therapy and Comparative Criminology, 59(5), 480-501.

Freedman, D., Thornton, A., Camburn, D., Alwin, D., \& Young-DeMarco, L. (1988). The life history calendar: A technique for collecting retrospective data. Sociological Methodology, 18, 37-68.

Giordano, P. C. (2016). Mechanisms underlying the desistance process: Reflections on 'A theory of cognitive transformation'. In J. Shapland, S. Farrall, \& A. Bottoms (Eds.), Global Perspectives on Desistance (pp. 27-43). Routledge.

Giordano, P. C., Cernkovich, S. A., \& Rudolph, J. L. (2002). Gender, crime, and desistance: Toward a theory of cognitive transformation. American Journal of Sociology, 107(4), 9901064.

Harris, D. A. (2017). Defining and deconstructing desistance. In D. A. Harris (Ed.), Desistance from sexual offending (pp. 19-38). Palgrave Macmillan.

Healy, D. (2010). Betwixt and between: The role of psychosocial factors in the early stages of desistance. Journal of Research in Crime and Delinquency, 47(4), 419-438. 
Hirschi, T., \& Gottfredson, M. (1983). Age and the explanation of crime. American Journal of Sociology, 89(3), 552-584.

Hochstetler, A. (2002). Sprees and runs: Opportunity construction and criminal episodes. Deviant Behavior, 23(1), 45-73.

Josselson, R., \& Lieblich, A. (1993). The narrative study of lives. Sage Publications, Inc.

Kazemian, L. (2016). What are the most important studies of desistance and what are the future research needs? In L. Kazemian, (Ed.), Probation (pp. 35-59). Palgrave Macmillan.

Kazemian, L., \& LeBlanc, M. (2007). Differential cost avoidance and successful criminal careers: Random or rational? Crime \& Delinquency, 53(1), 38-63.

Laferrière, D., \& Morselli, C. (2015). Criminal achievement and self-efficacy. Journal of Research in Crime and Delinquency, 52(6), 856-889.

Laub, J. H., \& Sampson, R. J. (2003). Shared beginnings, divergent lives: Delinquent boys to age 70. Harvard University Press.

Laub, J. H., Nagin, D. S., \& Sampson, R. J. (1998). Trajectories of change in criminal offending: Good marriages and the desistance process. American Sociological Review, 63(2), 225238.

Loughran, T. A., Nguyen, H., Piquero, A. R., \& Fagan, J. (2013). The returns to criminal capital. American Sociological Review, 78(6), 925-948.

Loughran, T. A., Paternoster, R., Piquero, A. R., \& Fagan, J. (2012). “A good man always knows his limitations": The role of overconfidence in criminal offending. Journal of Research in Crime and Delinquency, 50(3), 327-358.

Maruna, S. (2001). Making good: how ex-convicts reform and rebuild their lives. American Psychological Association. 
Maruna, S., Immarigeon, R., \& LeBel, T. P. (2013). Ex-offender reintegration: Theory and practice. In S. Maruna \& R. Immarigeon (Eds.), After crime and punishment (pp. 21-44). Willan.

Maruna, S., LeBel, T. P., Naples, M., \& Mitchell, N. (2009). Looking-glass identity transformation: Pygmalion and Golem in the rehabilitation process. In B. Veysey, J. Christian, \& D. J. Martinez (Eds.), How offenders transform their lives (pp. 30-51). Willan Publishing.

McAdams, D. P. (1985). Power, intimacy, and the life story, Personological inquiries into identity. Homewood.

McCarthy, B. (2002). New economics of sociological criminology. Annual Review of Sociology, $28(1), 417-442$.

McCarthy, B., \& Hagan, J. (2001). When crime pays: Capital, competence, and criminal success. Social Forces, 79(3), 1035-1060.

Moffitt, T. E. (1993). Life-course-persistent and adolescence-limited antisocial behavior: A developmental taxonomy. Psychological Review, 100(4), 674-701.

Morselli, C., \& Tremblay, P. (2004). Criminal achievement, offender networks and the benefits of low self-control. Criminology, 42(3), 773-804.

Morselli, C., Tremblay, P., \& McCarthy, B. (2006). Mentors and criminal achievement. Criminology, 44(1), 17-43.

Nguyen, H., \& Bouchard, M. (2013). Need, connections, or competence? Criminal achievement among adolescent offenders. Justice Quarterly, 30(1), 44-83.

Nguyen, H., \& Loughran, T. A. (2017). On the reliability and validity of self-reported illegal earnings implications for the study of criminal achievement. Criminology, 55(3), 575-602. 
Nguyen, H., Loughran, T. A., Paternoster, R., Fagan, J., \& Piquero, A. R. (2017). Institutional placement and illegal earnings: Examining the crime school hypothesis. Journal of Quantitative Criminology, 33(2), 207-235

Ouellet, F. (2019). Stop and go: Explaining the timing of intermittency in criminal careers. Crime \& Delinquency, 65(5), 630-656.

Ouellet, F., \& Bouchard, M. (2017). Only a matter of time? The role of criminal competence in avoiding arrest. Justice Quarterly, 34(4), 699-726.

Ouellet, F., \& Tremblay, P. (2014). Épisodes d'inactivité et revenus criminels dans une trajectoire de délinquance [Episodes of inactivity and criminal income in a delinquency trajectory]. Canadian Journal of Criminology and Criminal Justice, 56(5), 527-562.

Paternoster, R., \& Bushway, S. (2009). Desistance and the feared self: Toward an identity theory of criminal desistance. Journal of Criminal Law \& Criminology, 99(4), 1103-1156.

Paternoster, R., Dean, C. W., Piquero, A., Mazerolle, P., \& Brame, R. (1997). Generality, continuity, and change in offending. Journal of Quantitative Criminology, 13(3), 231-266.

Piliavin, I., Gartner, R., Thornton, C., \& Matsueda, R. L. (1986). Crime, deterrence, and rational choice. American Sociological Review, 5(1), 101-119.

Pogarsky, G., Roche, S. P., \& Pickett, J. T. (2017). Heuristics and biases, rational choice, and sanction perceptions. Criminology, 55(1), 85-111.

Sampson, R. J., \& Laub, J. H. (1993). Structural variations in juvenile court processing: Inequality, the underclass, and social control. Law and Society Review, 27(2), 285-311.

Shover, N., \& Thompson, C. Y. (1992). Age, differential expectations, and crime desistance. Criminology, 30(1), 89-104. 
Sutton, J. E., Bellair, P. E., Kowalski, B. R., Light, R., \& Hutcherson, D. T. (2011). Reliability and validity of prisoner self-reports gathered using the life event calendar method. Journal of Quantitative Criminology, 27(2), 151-171.

Tremblay, P., Charest, M., Charette, Y., \& Tremblay-Faulkner, M. (2016). Le délinquant affilié: La sous-culture des gangs de rue haïtiens de Montréal [The affiliated offender: Haitian street gang subculture of Montreal]. Éditions Liber.

Tremblay, P., \& Morselli, C. (2000). Patterns in criminal achievement: Wilson and Abrahamse revisited. Criminology, 38(2), 633-657.

Uggen, C., \& Thompson, M. (2003). The socioeconomic determinants of ill-gotten gains: Within-person changes in drug use and illegal earnings. American Journal of Sociology, 109(1), 146-185.

Wang, W. (2013). Conventional capital, criminal capital, and criminal careers in drug trafficking [Doctoral dissertation]. Simon Fraser University.

Yoshihama, M., Gillespie, B., Hammock, A. C., Belli, R. F., \& Tolman, R. M. (2005). Does the life history calendar method facilitate the recall of intimate partner violence? Comparison of two methods of data collection. Social Work Research, 29(3), 151-163. 


\section{Tables}

Table 1: Descriptive statistics of criminal achievement by groups.

\begin{tabular}{|c|c|c|c|c|c|c|c|c|c|c|}
\hline & \multicolumn{2}{|c|}{$\begin{array}{c}\text { Criminal earnings per } \\
\text { year }(\$)\end{array}$} & \multicolumn{2}{|c|}{$\begin{array}{l}\text { Total criminal earnings } \\
(\$)\end{array}$} & \multicolumn{2}{|c|}{$\begin{array}{l}\text { Years spent } \\
\text { incarcerated }\end{array}$} & \multicolumn{2}{|c|}{$\begin{array}{l}\text { Time incarcerated } \\
\text { as a percentage of } \\
\text { criminal career }\end{array}$} & \multicolumn{2}{|c|}{$\begin{array}{c}\text { Number of } \\
\text { arrests }\end{array}$} \\
\hline & $\overline{\mathrm{x}}$ & SD & $\overline{\mathrm{x}}$ & SD & $\overline{\mathrm{x}}$ & SD & $\overline{\mathrm{x}}$ & SD & $\overline{\mathrm{x}}$ & SD \\
\hline Group 1 & $\$ 36090$ & 34999 & $\$ 376321$ & 336172 & 14 & 11 & $53.26 \%$ & 37.44 & 33 & 18 \\
\hline Group 2 & $\$ 91591$ & 46548 & $\$ 1026293$ & 873253 & 5 & 4 & $32.32 \%$ & 24.98 & 7 & 6 \\
\hline Group 3 & $\$ 217466$ & 180742 & $\$ 2897277$ & 3051535 & 2 & 2 & $17.87 \%$ & 19.55 & 2 & 3 \\
\hline
\end{tabular}

